\title{
Communication
}

[Comunicação]

\section{Histopathologic alterationsof gill tissue in Siluriformes and Characiformes from the Middle Tocantins River in the Brazilian Amazon}

\author{
[Alterações histopatológicas do tecido branquial em Siluriformes e Characiformes do \\ médio rio Tocantins, na Amazônia brasileira] \\ C.A.M. Bezerra ${ }^{1}$, A.L. Sousa ${ }^{2}$, D.C. Viana ${ }^{2}$ \\ ${ }^{1}$ Bolsista BATI - Universidade Estadual do Maranhão - São Luís, MA \\ ${ }^{2}$ Núcleo de Estudos Morfofisiológicos Avançados - Programa de Pós-graduação \\ em Ciência Animal - Universidade Estadual do Maranhão - São Luís, MA
}

The Tocantins-Araguaia basin, the largest located entirely in Brazil, consists of three stretches along its course: the upper, middle and lower Tocantins River. According to a current survey conducted, there is no information on fish health in the Middle Tocantins River, and this area has been classified as a high priority for biodiversity conservation by Ministry of the Environment Decree 5.092 of May 21, 2004 (Brasil, 2004).

The recent introduction of hydroelectric power plants and other chronic anthropic influences in the Middle Tocantins River threaten the sustainability of the ecosystem. Moreover, the water volume of the river, determined by the rainfall indices, has varied over the years, influencing the local fishing regime. Rainfall in the River Tocantins basin during the 2017 dry season (June to November) was lower than expected (Brasil, 2017), affecting the aquatic biota and changing the fishing season in the region. In this respect, histopathological studies have been used as a valuable tool in assessing the environmental impacts on fish populations (Cantanhêde et al., 2014).

Branchial investigations with environmental biomarkers are increasingly common worldwide (Albinati et al., 2009; Fonseca et al., 2016). However, this type of study on fish from the Tocantins River is nonexistent, making this investigation unprecedented in gill morphology.
Thus, the aim of the present study was to assess the occurrence of gill alterations in histological sections of fish from the Middle Tocantins River.

The research was conducted in the Middle Tocantins River in Embiral, Maranhão (MA) state ( $5^{\circ} 27^{\prime} 50^{\prime}$ S, $47^{\circ} 33^{\prime}$ " $48^{\prime}$ "W). The village of Embiral is part of the rural zone of Imperatriz, MA, located on the banks of the Tocantins River. The region features commercial and subsistence fishing. Fish were captured in nets and immediately packed in Styrofoam boxes filled with ice and taken to the Anatomy Laboratory of the State University of Tocantins (UEMASUL) for material processing.

The fish sample collection protocol and laboratory procedures were approved by the Research Ethics Committee of Maranhão State University (UEMA) under protocol number 21/2017, and the environmental collection license was obtained from the System for Authorization and Information on Biodiversity (SISBIO), protocol 61650-1. Three fish species were captured: Pimelodina flavipinnis (Steindachner, 1876), Pimelodus blochii (Valenciennes, 1840) and Psectrogaster amazonica (Eigenmann \& Eigenmann, 1889). The second gill arch from three specimens of each species were analyzed for comparative standardization purposes. 
The gills were fixed for 24 hours in $10 \%$ formaldehyde, washed and stored in $70 \%$ alcohol until histological processing. The second gill arch was dried in an increasing series of alcohols, diaphonized in xylol, impregnated and included in paraffin. Crosssections $(5 \mu \mathrm{m}$-thick) were made using a Leica microtome and stained with hematoxylin and eosin (H\&E).Tissue sections were analyzed for each organ of each animal. The slides were analyzedby optical microscopy (ZEISS) and the injuries photographed with a Leica DM500 photomicroscope.

Histological alterations according to Poleksic and Mitrovic-Tutundzic (1994) and adapted by Cantanhêde et al.(2014), were organized into stages I, II and III.The histological alteration index (HAI) is calculated for each organism using the following formula: HAI $=(1 \times \Sigma S I)+$ $(10 \mathrm{x} \Sigma \mathrm{SII})+(100 \mathrm{x} \Sigma \mathrm{SIII})$, in which $\Sigma$ SI, $\Sigma$ SII and $\Sigma$ SIII correspond to the sum totalnumber of alterations in stage I, II and III, respectively. Thus, the mean HAI result is divided into five categories: values between 0 and 10 indicate normal organ function; 11 and 20 slight damage; 21 and 50 moderate changes; 50 and 100 severe injury; and over 100 irreversible damage to the organ.

The specimens collected during the rainy season, in january, exhibited the following gill alterations: hyperplasia in all specimens of the three species (P. blochii, $P$. flavipinnis and $P$. amazonica), with partial or total lamellar fusion; filament epithelial detachment in $P$. blochii (two specimens) and P. flavipinnis (in all specimens); congestion in all specimens of $P$. blochii and $P$. amazonica; aneurysm in one specimen of the $P$. blochii and pulmonary lamellar shortening in two specimens of the $P$. amazonica (Figure 1).

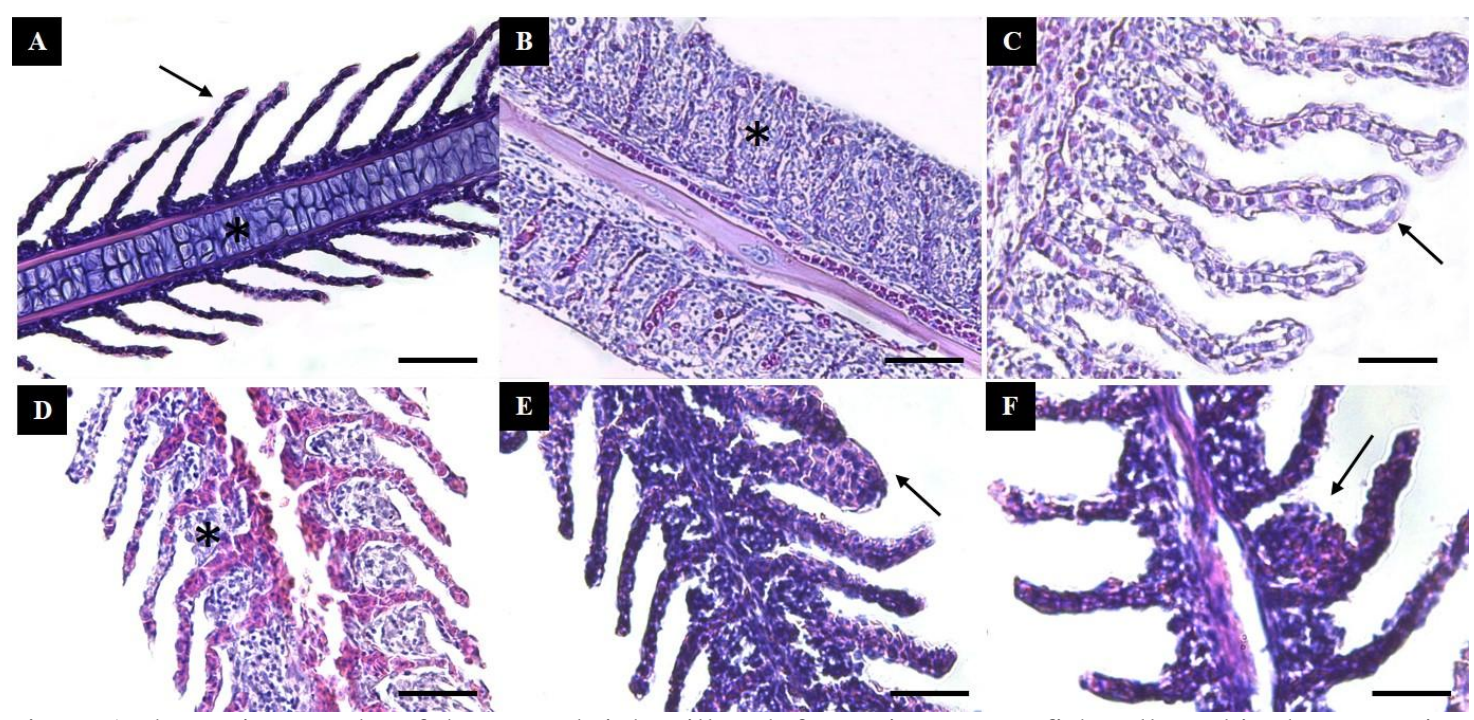

Figure 1.Photomicrographs of the second right gill arch fromrainy season fish collected in the Tocantins River, Embiral, Maranhão state, in the rainy season.A) Gill filament (asterisk) and normal respiratory lamellae (arrow); B) Hyperplasia with total respiratory lamellar fusion (asterisk); C) Filament epithelial detachment (arrow): D) Hyperplasia (asterisk); E) Lamellar congestion (arrow); F) Aneurysm (arrow).Bar: $50 \mu \mathrm{m}$.

In the typically dry periods (July and September), represented only by $P$. amazonica, the following injuries were identified: hyperplasia(five specimens), with partial or total lamellar fusion, rupture of the lamellar epithelium with hemorrhage(one sample), aneurysm(two samples), lamellar shortening (three specimen), epithelial lifting(one sample), vasodilation of primary lamellae(two samples), secondary lamellar thickening (one sample), gill filament necrosis(one sample)and disorganization (three sample) (Figure 2).

Regarding $P$. amazonica, representative of both dry and rainy seasons, mean HAI was 5.3 in the latter and 53 in the former, demonstrating that 
the gills of individuals sampled in the dry season exhibited significant tissue changes. This may be related to the low water level of the river due to the high concentration of pollutants. Unlike other studies (Cantanhêde et al., 2014), the HAI was higher in the rainy season, in which gill injuries were more frequent. $P$. flavipinnis and $P$. blochii presented HAI values corresponding to 3.6 and 37.6 respectively, demonstrating that the second species expresses greater anthropic influence in relation to the first in the rainy season.

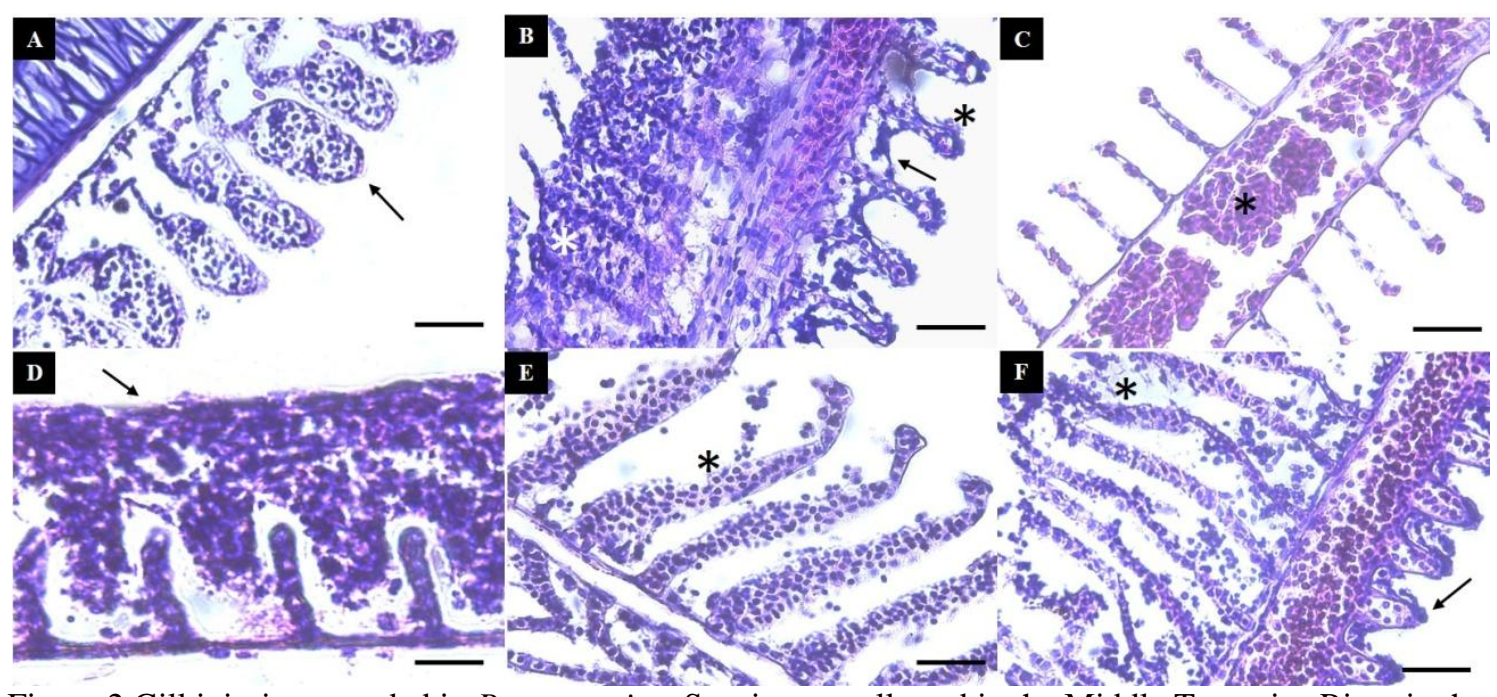

Figure 2.Gill injuries recorded in P. amazonica. Specimens collected in the Middle Tocantins River in the dry season; A) Aneurysm (arrow); B) Hyperplasia (white asterisk), lamellar shortening (black asterisk) and epithelial lifting (arrow); C) Primary lamellar vasodilation (asterisk); D) Uncontrolled epithelial thickening (arrow); E) Secondary lamellar thickening with epithelial rupture and hemorrhage (asterisk); F) Necrosis (asterisk). Bar: $50 \mu \mathrm{m}$.

When fish are faced with changes in their oxygen needs, the following adjustments may occur: change in water flow through the gills, change in blood flow inside the gills or remodeling of gill morphology (Santos Filho et al., 2014). This last process was observed in the captured specimens. The change in the primary shape of the respiratory lamellae demonstrates adaptation to the presence of possible contaminants in the water, aimed at decreasing the contact of pollutants with the organ responsible for breathing, in this case, the gills. A predominant trait in the fish analyzed was lifting of the respiratory epithelium, included in stage $\mathrm{I}$, in both the dry and rainy seasons. This is a common response of fresh water fish to water pollution, and is considered the first sign of gill pathology.

Lifting of the lamellar epithelium was observed at the apex of the secondary lamellae and, in another specimen, at the base of the filament associated with lamellar shortening. A study in the Laguna da Jansen Ecological Park, located in the metropolitan area of São Luis, in Maranhão state found that this injury was the most frequent, occurring laterally on the respiratory lamellae in the species Centropomus undecimalis (Bloch, 1972) (Cantanhêde et al., 2014). These observations indicate that this type of injury may occur on parts or along the entire secondary lamellae and may or may not be associated with another type of injury.

The present study also recorded shortening of the respiratory lamellae in $P$. amazonica during the dry and rainy seasons. This type of injury, belonging to stage I, causes a restructuring of the pillar cell system, exhibiting more than one column of pillar cells that sustain the respiratory lamellae. It may result from contraction of the secondary lamellae with a view to reducing contact between the blood and the pollutant.

Poleksic and Mitrovic-Tutundizic (1994) reported that the shortening in the secondary lamellae may cause total fusion, which could influence the gas exchange process in the gills, provoking insufficient gas diffusion between the 
lamellae.Other studies involving exposure to chemical compounds demonstrate shortening of respiratory filaments (Barja-Fernández et al., 2013). Even when temporary, these biological responses to possible contaminants in the water may trigger changes in gill morphology in an attempt at reducing contact with the pollutant, as demonstrated here(Fonseca et al., 2016).

The vasodilation, stage I, observed in P. amazonica during the dry season only reached the central venous sinus of the gill lamellae without affecting their lining epithelium. A similar condition also occurred in fish upstream and downstream from a wastewater treatment plant on the Paiva River in Portugal (Fonseca et $a l ., 2016)$, where it is suggested that the injuries are characteristic of exposure to different types of pollutants, including agricultural leachates and domestic waste acting in different sectors of the hydrographic basin.

The aneurysm in $P$. amazonica was present in the dry and rainy seasons, thereby compromising gas exchanges.In the classification used by Poleksic and Mitrovic-Tutundizic (1994) and adapted by Cantanhêde et al. (2014), an aneurysm belongs to stage III, considered irreparable even if water quality improves.

Epithelial necrosis and rupture of the gill epithelium, corresponding to stage III and season II, observed in the present study are irreversible conditions that are generally, but not specifically, attributed to metal (Mallatt, 1985) and sediment contamination (Winkaler et al., 2008). Degeneration from necrosis and apoptosis of gill epithelial cells was also reported in studies conducted with teleosts exposed to different pollutants in Brazil and worldwide (Pereira et al., 2013; Santos Filho et al., 2014).
The benthopelagic behavior of $P$. amazonica, that is, in close contact with the sediment, may indicate that the sediments are contaminated. In a study carried out in the Sinos River in Rio Grande do Sulstate during the four seasons of the year, chemical analyses that compared water, sediment and fish showed that the highest heavy metal content was found in the sediment (Weber et al., 2013). Thus, further studies are necessary, covering the analysis of sediments of the Tocantins River. Injuries are related to high gill sensitivity to environmental stress and their ability to react even at low concentrations and over short time periods.

The species $P$. flavipinnis and $P$. blochii exhibited less serious injuries. $P$. amazonica displayed several types of gill histopathology, including marked severity, such as necrosis and aneurysm, important irreversible conditions. The gill injuries recorded in $P$. amazonica were most commonly observed in specimens captured at the waste treatment plant in the dry season. $P$. amazonica showed potential as a model in biomarker investigations due to its ability to survive in a contaminated environment. The injuries observed likely originated in pollutants accumulated in the Tocantins River.

\section{ACKNOWLEDGMENT}

Coordenação de Aperfeiçoamento de Pessoal de Nível Superior (CAPES) and the Fundação Maranhão de Apoio à Pesquisa e Desenvolvimento Científico e Tecnológico (FAPEMA), for research assistance to author C.A.M. Bezerra.

Keywords: freswater fish, histopathological, respiratory epithelium

\section{RESUMO}

As águas do rio Tocantins têm sofrido descargas de dejetos tóxicos que ameaçam a biota aquática. Para tanto, a investigação das brânquias de peixes atua como biomonitoramento, visto que esses órgãos respondem por meio de adaptações a xenobióticos. Este trabalho teve como objetivo avaliar a ocorrência de alterações morfológicas das espécies de Psectrogaster amazonica, Pimelodina flavipinnis e Pimelodus blochii. As coletas ocorreram nas estações chuvosa e seca. As brânquias de todos os espécimes coletados foram processadas de acordo com metodologia específica para protocolo de hematoxilina e eosina. As principais alterações histológicas observadas no período chuvoso foram: hiperplasia, destacamento do epitélio filamentar, fusão parcial e total das lamelas secundárias, congestão, aneurisma e encurtamento das lamelas respiratórias. Em relação ao período seco, as principais lesões observadas foram: ruptura do epitélio, aneurisma, hiperplasia e necrose. 
Considerando a diversidade ictiológica do rio Tocantins, o presente estudo propiciará o conhecimento da condição das brânquias, órgão imprescindível para a saúde do peixe, e consequentemente a compreensão das implicações sobre a qualidade das águas do rio Tocantins.

Palavras-chave: peixe de água doce, histopatologia, epitélio respiratório

\section{REFERENCES}

ALBINATI, A.C.L.; MOREIRA, E.L.T.; ALBINATI, R.C.B. et al. Histological biomarkers: chronic toxicity for roundup in piauçu (Leporinusmacrocephalus). Arq. Bras. Med. Vet. Zootec., v.61, p.621-627, 2009.

BARJA-FERNÁNDEZ， S.; MÍGUEZ， J.M.; ÁLVAREZ-OTERO, R. Histopathological effects of 2,2',4,4'-tetrabromodiphenyl ether (BDE-47) in the gills, intestine and liver of turbot (Psetta maxima). Ecotoxicol. Environ. Saf., v.95, p.60-68, 2013.

BRASIL. Ministério do Meio Ambiente. Decreto $n^{\circ}$ 5.092, de 21 de maio de 2004. Define regras para identificação de áreasprioritárias para a conservação, utilização sustentável e repartição dos benefícios da biodiversidade, no âmbito das atribuições do Ministério do Meio Ambiente. Diário Oficial, Brasília, DF, 21 maio 2004.

BRASIL. Ministério do Meio Ambiente. Agência Nacional de Águas, Boletim Diário de Monitoramento da Bacia do Rio Tocantins, 2017. Disponível em: <http://www3.ana.gov.br/portal/ANA/sala-desituacao/tocantins/boletins-tocantinsdiario/tocantins-bol-diario-31-10-2017.pdf> . Acessado em: 30 mar.2019.

CANTANHÊDE, S.M.; MEDEIROS, A.M.; FERREIRA, F.S. et al. Uso de biomarcador histopatológico em brânquias de Centropomusundecimalis (Bloch, 1972) na avaliação da qualidade da água do Parque Ecológico Laguna da Jansen, São Luís - MA. Arq. Bras. Med. Vet. Zootec., v.66, p.593-601, 2014.
SANTOS FILHO, F.M.; REZENDE, K.F.O.; EMERENCIANO, A.K. et al. Avaliação de biomarcadores histológicos em peixes coletados a montante e a jusante da mancha urbana. Atas Saúde Amb., v.2, p.9-22, 2014.

FONSECA A.R.; SANCHES FERNANDES, L.F.; FONTAINHAS-FERNANDES A. et al. From catchment to fish: Impact of anthropogenic pressures on gill histopathology. Sci. Total Envir., v.550, p.972-986, 2016.

MALLATT, J. Fish gill structural changes induced by toxicants and other irritants: a statistical review. Can. J. Fish. Aquat. Sci., v.42, p.630-648, 1985.

PEREIRA, S.; PINTO, A.L.; CORTES, R. et al. Gill histopathological and oxidative stress evaluation in native fish capturedin Portuguese northwestern rivers. Ecotoxicol. Environ. Saf., v.90, p.157-166, 2013.

POLEKSIC, V.; MITROVIC-TUTUNDZIC, V. Fish gills as a monitor of sublethal and chronic effects of pollution. In: MÜLLER, R.; LLOYD, R. (Eds.). Sublethal and chronic effects of pollutants on freshwater fish. Oxford: FAO, Fishing News Books, 1994.

WEBER, P.; BEHR, E.R.; KNORR, C.D.L. et al. Metals in the water, sediment, and tissues of two fish species from different trophic levels in a subtropical Brazilian river. Microchem. J., v.106, p.61-66, 2013.

WINKALER, E.U.; SILVA, A.G.; GALINDO, H.C.; MARTINEZ, C.B.R. Biomarcadores histológicos e fisiológicos para o monitoramento da saúde de peixesde ribeirões de Londrina, Estado do Paraná. Acta Sci. Biol. Sci., v.23, p.507-514, 2008. 